\title{
Crisis of the Policy of Multiculturalism and National Security in Western Europe
}

\author{
Vyacheslav Aleksandrovich Mikhailov ${ }^{1}$
}

\author{
Tanzilya Altafovna Nigmatullina² \\ ${ }^{1}$ The Russian Presidential Academy of National Economy and Public Administration \\ ${ }^{2}$ Bashkir Institute of Social Technologies of Academy of Labor and Social Relations
}

Doi:10.5901/mjss.2015.v6n6s3p179

\section{Abstract}

\begin{abstract}
After the September 11, 2001 terrorist attacks in the United States of America, the threat of terrorism has become evident to leaders of the Western democracies, forcing them to face the challenges of fighting this threat from a new standpoint. Amid universal globalization and integration, Western European countries set a course for the policy of multiculturalism which was supposed to blur foreign-culture differences within a common system of the Western European civilization. As of today, however, the leaders of the three most prominent Western democratic countries (Great Britain, Germany, France) have already admitted failure of multiculturalism as a worldwide "melting pot". But are there alternatives to multiculturalism today? How a person can be made to "love" a follower of other cultural traditions? These and many other issues are covered in this article. Its purpose is to analyze the impact of international events (from Afghanistan to the present-day Ukraine) of European policy and cultural differences on the dynamics of this phenomenon, as well as investigate causes of radicalization trends in the liberal democratic society -which is especially relevant with regard to the international terrorism and extremism fighting effort. The author concludes that the crisis of multiculturalism does not necessarily mean its rejection and believes that the policy's emphasis should be first shifted to a municipal level ("municipal multiculturalism"), to be ranked up as a nationwide objective only after positive results are obtained.
\end{abstract}

Keywords: democracy, terrorism, Western Europe, multiculturalism, municipal level.

\section{Introduction}

It is obvious that in the $21^{\text {st }}$ century, counter-terrorism has become one of the key national security tasks for every country, regardless of its geographical location, size, population or economic status. Democratic countries with a welldeveloped social infrastructure, mass media (hereinafter, media) manipulating public opinion in pursuit of profits and a high level of modern information technology employment in their economic and administrative structures are most vulnerable to terrorist actions (Vishnyakov, 2012).

But why was it Western Europe that became a large-scale scene for terrorist threats? The answer is self-evident, and in our opinion it is strongly related to the forms and methods through which democratic values are institutionalized in the West. In no way it is meant to say that terrorism is a product of the democratic thought. It rather means that it is easier for terrorism to develop in a democratic environment and 'lose' itself in the intricacies of liberal paradigms.

According to Attari Amjad Sabri, terrorism poses a threat to democratic trends both inside and outside a country. On the one hand, the lower the population's educational level is, the weaker its social security and the more "meteredout" information flows, the lesser part it plays in the decision-making process within a country. On the other hand, a country which no longer lives up to its citizens' needs and aspirations cannot be a full-fledged participant in international relations because it ceases to assert its own interests and follows the dictate of global economical structures (Attari, 2014).

Besides, it was Western Europe that stood at the origins of fostering nations' rights to self-determination and carrying out a world proletarian revolution against the world of capital, to be later used by terrorists (and others besides terrorists) in pursuance of their political schemes.

Western authors pose themselves against a dubious dilemma, having to choose between "securitization" and militarization of development agenda, on the one hand, and total individualization of security challenges, on the other. While some investigators and politicians were prone to bending towards political realism, causing interests of the "weak" states to be ignored, proponents of the person-centered paradigm go too far in the opposite direction. They seek to entirely embrace the "person-centered" approach, bypassing the country- and nation-building stages and considering the 
state as part of the problem, rather than its solution (Poku \& Renwick, 2007).

I.F. Lupov in one of his works identifies factors of an institutionalization of terrorist activity in the western democracies:

- Western Europe is a geographically compact area with excellent transport infrastructure and the increasingly easy to cross borders.

- Here, being guided by the principles of a freedom of speech, firm for liberal democracy, and, respectively, freedom of mass media, terrorists have opportunity to extend the ideas and views most widely.

- High extent of industrialization of Western Europe lead to the fact there is a set of potential objects for terrorists' attacks in this region.

- Ethno confessional, socio-cultural and political heterogeneity of the West European societies in a certain degree facilitates to terrorists a task "to hide" in the region (Kymlicka, 2012).

- Western Europe is characterized by certain moral and philosophical traditions, which can only improve the efficiency of terrorism to achieve political goals.

Soviet Union crash and reunion of the Western and considerable part of Eastern Europe also made the West European civilization more vulnerable to this type of political violence. Withdrawal of the Soviet forces from Afghanistan has also strengthened the positions of terrorist organizations in liberal democracies.

As a result of sharp political destabilization of the Soviet Union an access to the weapon for terrorists became much easier on the post-Soviet territory. Terrorist groups had an opportunity to involve in the activity the high skilled professionals, who were former military and security servants and also scientists-developers of mass destruction weapons of the former communistic bloc, who appeared to be unclaimed in the new independent countries (Luppov, 2009 \& Luppov \& Gribanova, 2009).

The West European civilization which won socialist camp, blurring economic boundary between its countries has completely forgot about the security measures (there is nobody to afraid of. Soviet Union is no longer exists). And only later it became obvious that refusal of customs and passport control inevitably leads to creation of more favorable conditions for different activities of criminal elements, including terrorists.

If to consider evolution of Islamic terrorism in Western Europe, we can see that it was undergone certain transformations (Ghanea, 2010). Especially it would be desirable to note that the phenomenon of Islamic terrorism in Western Europe would clearly have other forms and scope in case of non existence of impressively sized Muslim community. Moreover, if its formation was the result of consecutive migratory and integration politics, the internal tension connected with formation of the "foreign culture" closed clusters would be lesser as it would also be in relation to the feeling of "foreignness" and "not belonging" to the European society felt by migrants and their descendants (Ledeneva, 2014).

According to N. A. Myazin" ... Strengthening of Islamists' position was due to the failure of the idea of Arab socialism, economic success of Salafi Saudi Arabia and the military conflicts in Afghanistan and Bosnia" (Myazin, 2013).

The Salafi international terrorism can be considered as a radical and global, as it is opposed to the traditional way of the Muslim community, the Ummah. Its main object is opposition to the Western global project.

The most important concept for the Salafi movement is jihad. It was drawn in order to get around the obstacle that embodies the Sunni negation of fitnah in Ummah that is the negation of violence against the country in this direction of Islam. The first person to beat this obstacle was Muhammad ibn Abd-al-Wahhab, the founder of Wahhabism (Wahhabism [Electronic resource] // Website of "World Religions» URL: http://relig.info/vakhkhabizm). His activity came to the XVIII century and ended in the subordination of all the Arabian Peninsula. He argued that the war against Muslims is justified because the Islamic world is in a state of Jaahiliyyah, barbarism and godlessness. Later the same argument was resorted by Sayyid al-Qutb, who lived in the first half of the XX century, the ideologist of "Muslim Brotherhood" in Egypt. Inspired by his ideas, Salih Sirriyya, one of the leaders of the radical Islamists, attempted a coup in Cairo, which was suppressed. Another of his successor - Shukri Mustafa - founded the "Society of Muslims (Karpachova, 2007)" tending, like Mohammed, who went into exile to Medina, to escape from corrupt society and there to preserve the "purity of the faith". Here we meet with the strategy of "escape", an attempt to hide from the Western culture, to fence dimensionally. It is not surprising that this strategy failed: by 1977 the organization was destroyed as a result of persecution by Nasser secularized regime.

Daniel Pipes points out: "The purpose of jihad is not so much the spread of the Islamic faith, as the expansion of the sphere of influence of the sovereign Muslim power. Therefore, jihad by nature is unabashedly aggressive, and its ultimate goal is to achieve the rule of Muslims over the world (Pipes, D. What is Jihad?, http://www.danielpipes. org/990/what-is-jihad)". Although journalistic sharpness and controversial characteristic, it complements to some extent jihad characteristics in the "renewed" Islam. This is confirmed by the description of practice and theory of jihad on an 
Islamist site which is based on the book of Sheikh Abu Mus'abom al-Suri "The Call of Worldwide Islamic Resistance". It states that Jihad in recent decades has ceased to be a war between the two countries and became partisan completely (Drinova, 2013). He underlines the three main types of partisan jihad:

- Jihad of underground hierarchical organization, such as "The Fighting Vanguard" in Syria in the 1970s - 1980s, the Egyptian "Islamic Jihad";

- Jihad of open fronts, for example, in Afghanistan during the Soviet intervention in Bosnia and Chechnya during the first war;

- Jihad of "singles" - operations of small (starting from one person) units not physically connected with some large organizations (Hacharoevsky, http://hunafa.com/?p=13454).

\section{Materials and Methods}

In order to understand the tendencies of this confrontation we have to deep ourselves in the history of relations between the Islamic civilization and the civilization of the West. After the initial broad expansion in VIII - IX centuries the Islamic world stopped its widening near the borders of France, seized the Iberian Peninsula and thus initiated the Reconquista. It was a time of arts and sciences development, as well as it was a time of the internal fragmentation. Islamic culture and religion were the only fixing thread between the independent Khaliphats. The counter attack has been done by the Christian world - in the form of Crusades. This event had a great impact on both European and the Islamic worlds. At that time the first organization has appeared which can be conventionally called terrorist and Islamist. It was the "Assassins", the branch of the Ismailis sect (History of Assassins, http://artassassins.narod.ru/Index.html). The sect of Assassins has a lot in common with the modern terrorists: they were fighting both against the "infidels" and the Muslim Rulers, they used the tactic of individual terrorism, they were glorifying the martyrdom for the faith. The Assassins terrified both Christians and Muslims until they have been destroyed by the Mongols in the XIII century. The very Crusades which are interesting now only for historians in the Western world became one of the ideological clichés of propaganda in the Middle East. In their statements, the Islamist leaders often refer to the designation of "crusaders" B. Lewis (2003) when speaking about theenemy "from the West".

During the following centuries the world of the East has remained on the periphery of the World history (that is to say, on the periphery of European history). It was rather the place of unfolding struggle between the European powers, as, for example, in the case of Napoleon's Egyptian campaign the main purpose of which was to fight with the British influence on Egypt. It seemed that the twentieth century would not change this scheme. When Lawrence of Arabia was sent to help the Arabs in order to rise a rebellion against Turkey they were given a secondary role and their success has become a kind of sensation (Lawrence of Arabia, http://allpersons.name/index.php?option=com_content\&task=view\&id= 473\&ltemid=17). That time the Islamic world again set foot on the stage of history.

At the present moment we can define with a certain degree of conditionality, of course, several theories (or rather, its interpretations) of jihad which became now the ideological dogmas of terrorists. Firstly, it is the theory of classical jihad of Abdullah Azzam and its application in Afghanistan, Bosnia, Tajikistan and Chechnya. This theory is based on the panIslamic ideas encouraging taking a side of the Muslim Brothers involved in a military conflict regardless their ethnicity and nationality. It is a breaking point of this theory with the traditional doctrine of jihad. The traditional doctrine of jihad presupposes that only those who are in immediate danger could be involved in a conflict. The special attention in this theory is devoted to the emergence of the "martyrs" concept.

Secondly, it is Osama bin Laden theory of global jihad. The theory has appeared in the context of global political processes. Under the influence of these processes Bin Laden and his allies came to the conclusion in the late 90s about necessityto start the fight against the "far enemy" - the US and its allies. At the same time, if the ideological side of the "global jihad" was formulated by Bin Laden which became a symbol of jihad against the West, the strategic side of this global war was described by the other "strategist" - al-Suri, who argued the necessity to use the formula "nizam, la tanzim" (arab. The system, not the organization). Al-Suri has managed to combine the experience of past jihads and to analyze the major mistakes. That is the point which distinguishes his work from other books written, as a rule, in religious language. Later the idea of Al-Suri had been borrowed by the other jihadists in various parts of the world, for example, in Iraq.

Thirdly, it is a theory of universal jihad of the Islamic State (Islamic State of Iraq and the Levant). So, at the end of 2014 a terrorist group known as "Islamic State" has distributed by the World Wide Web the audioreference of their leader Abu Bakr al-Baghdadi in which he was calling to the "universal jihad". In his speech al-Baghdadi said that the campaign of US and other countries directed against terrorism in Syria and Iraq "was defeated" and he asked the supporters to "light the volcanoes of jihad around the world" (The Leader of ISIS, http://www.aif.ru/society/safety/1381626). 
To implement the information policy of "Islamic State of Iraq and the Levant" it was created the wide media infrastructure. Back in 2006 the "Al Qaeda" and "Islamic State of Iraq" have created a media agency "Al-Furqan" (alFurqan Institute for Media Production), which became the main center of wide range media products promotion including movies, audio and DVDs, brochures as well as the information materials for distribution in Internet. In a press release of "Islamic State of Iraq" this media agency was called "a milestone on the way to Jihad; the renowned media, which makes a significant contribution to the fight against the Crusaders and their helpers and reveals the lie of Western media". (A new quality of terrorist propaganda, http://spkurdyumov.ru/biology/novoe-kachestvo-terroristicheskoj-propagandymediaimperiya-igil/) Thus the "Islamic State of Iraq and the Levant" is a terrorist organization which has a developed media infrastructure and demonstrates the high level knowledge of advanced information and communications technologies (including the methods of work in social networks). It allows the group to promote an active propaganda of jihad in global scale and to recruit the new supporters in all parts of the World. The competent information policy of "Islamic State of Iraq and the Levant" along with its military actions contributed to the rise of the organization among other terrorist organizations in the Middle East and made the "Islamic State of Iraq and the Levant" the world's known organization. Currently the organization plays a key role in legitimizing of the created "Khaliphat" in the eyes of the Muslim Ummah.

Countries of Western Europe pursued a policy against terrorism as a response to threat to international security. Current methods of fighting against terrorism can be found, for example, in the government document "France against terrorism" (The French White Paper on defence and national security http://www.elysee.fr/download/). Mechanisms to fight against terrorist attacks were defined in it, such as:

- continuation of the practice of concluding bilateral agreements on air safety with neighbor countries to improve detection of suspicious air targets;

- active involvement of the national army to repel threat both in France and abroad;

- providing air traffic monitoring, constant readiness to intercept suspicious air targets, as well as aircrafts on board of which "unrests" were broken out;

- increasing of control over electronic communications, facilitating access for special services to different public and private databases;

- increasing control over suspicious foreigners, who arrives in the country.

Though, the French government clearly understands that it is impossible to neutralize the terrorist threat using just force. Concerning this within the multicultural course in France was formed the French Council of the Muslim Faith. The main purpose of this multicultural institute was to help Muslim clerics to prevent the Islamic "Jihad" in France. However, in 2008 representative of radical Islam came to power. It should be noted that the French legislation in the field of fighting against terrorism - one of the most demanding and rigorous in the world. However, even violent methods can't fully prevent terrorist threats.

As a proof - January 7, 2015, when terrorists broke into the building of Charlie Hebdo newspaper in Paris and opened fire on employees. As a result, 12 people were killed, including 10 editorial staff and two police officers (http://gordonua.com/news/society/Daydzhest-7-yanvarya-Terakt-v-Parizhe-evro-i-neft-upali-morozy-v-Ukraine-60097. html).

Thus, no force, no policy of multiculturalism has yielded the expected results. (Thor, 2014) Moreover, heads of Germany, Britain, France and the Netherlands government stated that attempts to build a multicultural society in Western Europe suffered a devastating collapse (http://www.nvspb.ru/stories/dobro-pojalovatotsyuda-44722).

\section{Discussion}

So why the policy of multiculturalism has not taken the root on the ground of democratic Europe? (Malik, 2013)

In accordance with the opinion of V.Lukov "... First of all, we have to see in multiculturalism the policy that encourage an immediate co-existence in the same area and at one time such people which represent different cultures; these people preserve each of their culture protecting it from absorbing by the dominant culture. Usually it is emphasized that multiculturalism is founded on the equality or equal value of different cultures - large or small, but it is rather a showcase of the particular ideological political line. The true idea is the following: instead of the cultural assimilation of immigrants the more rational alternative is to give them an opportunity to cultural autonomy by granting them the appropriate rights for the collective entities (one may call it the diaspora). In this case "natural selection" and the struggle for survival of the cultures could be replaced with intercultural dialogue - thedream of the Humanists of XX and XXI centuries. But what we really need is to respect the cultural needs of immigrants (and localizein such a way this constant source of social tension), to give them an opportunity to educate children and to solve the other questions, including 
political. In exchange it is expected that the representatives of other cultures get to be involved in the life of societyaccording to the rules of that society" (http://iph.ras.ru/uplfile/histan/kruglye_stoly_pdf/chto_oznachaet_krah_ mulwthkulwturalhzma_pdf).

But namely this one last effect, eventually, was not succeeded. Many of peoples and ethnic groups living in democratic countries do not respect the Western culture and feel to it nothing but the indulgence (Behloul, Leuenberger \& Tunger-Zanetti, 2014). If the Europeans have won the right to enslave and exploit the other people, those people, in turn, allow themselves tomystify the Western people. No one culture can demand the absolute universalization or the ultimate cult differences.

In our view, a promising way of multiculturalism development is the Soviet experience in solving the national problem. This experience, of course, had a lot of the shortcomings and tragic pages, but nevertheless, as a whole, it was a great historical achievement. For example, the cultural level of Soviet public discussion about national problems was very high.

But the West does not aim to recognize and to use the advantages of the Soviet Union in the sphere of intercultural relations,in particular, in the constitutional organization of society and institutions of the national policy of the Soviet "ghost".

Medvedev D.A in one of his speeches said: "We cannot allow ourselves to be provoked into arguments about the crash at multiculture... If we talk about the failure of multiculture, it is possible to destroy the tradition, but it is a danger and it has to be realized in the European countries too... The truth is that in all our democratic societies we are very deeply concerned about the identity of those who come into the country and we are not concerned enough about the identity of those who accept them" (http://www.utro.ru/articles/2011/02/11/955701.shtml). This is indeed very difficult to argue with.We believe that the municipality authorities have a special role in preventing and combating terrorism as well as in the development of multiculturalism. According to Gorbenko A.I. "... The communication with people, getting the operational information could become a significant asset in the fight against contemporary terrorism and its global manifestations" (Gorbenko, 2014).

The really problematic area in the municipal authorities' activities is the confidential interaction with the citizens (Herbert, 2013). The analysis of data shows us that today there are such problems as encountered people distrust to the authorities, to the police and other force structures, the insufficient awareness of people, the lack of security culture, the people unwillingness to show the civic activity and initiative (Demetradze, 2014).In this situation the sociological researches - both quantitative and qualitative methodologies - have a crucial role. These researches are designed to set the feedback of municipalities with population and to provide the governor structures with the necessary information. This information may allow us to take more effective and scientifically grounded solutions.

\section{Research Results}

On the base of Bashkir Institute of Social Technologies in May 2014 - January 2015it was conducted a questionnaire survey of experts from among the representatives of local governments and non-governmental organizations (53 respondents in total) and migrants (in the Bashkir Institute of Social Technologies in 2014 the Center of exams in Russian language was opened for migrants applying for Russian citizenship or for the employment permission) (428 persons in total). The questionnaire survey was about the counteraction to terrorism at the local level.According to the results of the research it's possible to conclude about the follows. The majority of the surveyed experts believe that the public opinion currently is not used enough, especially in the organization of counter-terrorism system at the local level.

In this regard, the experts pointed out the need to strengthen the outreach work with the population (including migrants) on the subordinated territories with the active use of media resources. In their view such work namely is going to optimize the situation with the use of public resources in the municipalities to counter terrorism.

The interviewed experts believe that, first of all, it is important to improve the outreach and to optimize the research support of the population. This aspect namely can be considered as a hidden reserve for the situation of country security policy constitution and development at the municipal level, including the development of multiculturalism in the country.

Based on the results of the questionnaire the author points out that the problem of terrorism and ethnic conflicts is relevant in varying degrees for $25 \%$ of migrants: $9 \%$ - "very relevant" and $16 \%$ - "rather relevant". The majority - $75 \%$ of respondents - believe the opposite, without giving much importance to the issue of terrorism and ethnic conflicts (44\% "rather irrelevant" and 31\% - "totally irrelevant"). Thus, according to the point of view of migrants, the problem of terrorism and ethnic conflicts albeit to a small extent, but it is somehow relevant to the Russian Federation, which is definitely confirmed by the objective circumstances.

Most of migrants perceive terrorism and international conflicts, firstly, as a threat to their personal safety (63\%). 
Quite common viewpoint is identification of the terrorism as a threat to their loved ones (21\%). Also, there is less popular point of view, according to which terrorism is threat to all Russians (12\%). For $4 \%$ of respondents it's difficult to answer. Such distribution of views can be explained by different psychological characteristics of people, who most acutely perceive threats which concern their personal safety and safety of their families, and then the safety of others and the country in general.

According to the point of view of migrants, acts of terrorism should be stopped by a balanced policy of the country (23\%) and to persuade ordinary citizens of the need for joint actions against terrorists (73\%). $4 \%$ of respondents were undecided on this issue.

Thus, the majority of respondents are aware of the real problem of terrorism, perceiving it as a threat to personal safety and the safety of their loved ones. At the same time, migrants are rather satisfied with the actions of the Russian authorities to combat terrorism. It should be noted that migrants are significantly affected with the media, it is particularly evidenced by a collective image of a terrorist, inspired by TV, press, internet etc.

\section{Conclusion}

In conclusion, we note that the effective inter-regional organizations and other formats of inter-regional cooperation render special value in combating terrorism and building of actionable multiculturism model (Abbas, 2011).

An example of anti-terrorist activity of regional organization, that was built not on weakening and mutual reinforcement members would be the Shanghai Cooperation Organization (SCO), whose main objective in the field of security is mutual assistance in combating member countries against terrorism, separatism and extremism (also known as "three evils") (The Shanghai Convention on Terrorism, Separatism and Extremism Combating, 2001).

But what's the difference between the SCO and other (mainly western) international organizations? The wording used for terrorism, extremism and separatism demonstrates that the SCO, unlike many international organizations, does not infringe in any way the sovereignty of member countries and strives to strengthen their domestic consolidation. Moreover, today the SCO countries cooperation is the furthest advanced in fighting terrorism. Since 2004 operates the Regional Antiterrorist Structure (RATS), having its center in Tashkent and uniting representatives of the security services. Participants intend to develop cooperation in terrorism financing termination as well as in elimination of the causes fueling global terrorism (for example, illegal traffic of drugs, social unrest etc.). The practical side of RATS is represented by regular anti-terrorist exercises and common database of terrorist organizations and persons involved in terrorist activities. We believe that regional organizations like the SCO are optimal platforms for coordination of national counter-terrorism strategies and joint activity. They also contribute to the political strengthening of the weak countries, protecting them from external influences both in the literal sense (intrusion), and in the information. The regional level is independent and is not a part of any global structure. But this does not mean that the global level of cooperation in the field of security should be rejected as unnecessary. Just pretending to be global, we should not be "brainwashed" in the well-known principles of Western democracy. We should begin with municipalities and regions, and then the multiculturalism problems will be eliminated.

\section{References}

Vishnyakov, Ya.D. (2012) Counter-terrorism: textbook for students of higher professional educational institutions / Ya. D. Vishnyakov, S. P. Kiselev, S. G. Vasin; edited by Ya. D. Vishnyakov. M.: Publishing center "Akademiya". pp. 256.

Attari, A.S. (2014) Political Terrorism and Security in the System of Modern International Relations // Dissertation of Doctor of Philosophy in Political Science. M. pp. 102.

Poku, N.K. \& Renwick, N. (2007) Porto J.G. Human security and development in Africa II International Affairs. Vol. 83. No. 6. pp.1170.

Kymlicka, W. (2012) Multiculturalism: Success, Failure and the Future. Migratio Policy Institute.

Luppov, I.F. (2009) Western European Democracies in the Fight Against Terrorism. Monograph. Saint Petersburg: Book House. pp. 113114.

Luppov, I.F. \& Gribanova, G.I. (2009) Counter-Terrorism as a Function of the Modern Country: Experience of West European Democracies (in collaboration). Monograph. Syktyvkar: CRAGSiU. pp. 89.

Ghanea, Bassiri K. (2010) History of Islam in America: From the New World to the New World Order. Cambridge University Press.

Ledeneva, V.Yu. (2014) International Aspects and Problems of Counteraction to Extremism in Modern Conditions // National Security / nota bene. No.2. pp. 207-216.

Myazin, N.A. (2013) Al-Muhajiroun: Preachers of Jihad on British Soil // Theory and Practice of Community Development. No.4. pp. 178180.

Wahhabism [Electronic resource] // Website of "World Religions» URL: http://relig.info/vakhkhabizm.

Karpachova, O. (2007) Ahmad Shukri Mustafa and "Muslim Society" // Asia and Africa Today. No.2. pp. 53-56. 
Pipes, D. What is Jihad? [Electronic resource] // Website «Daniel Pipes Middle East Forum» URL: http://www.danielpipes.org/990/whatis-jihad.

Drinova, E.M. (2013) Modernization and Globalization: Formation of Local Topos of Religion Politicization // Politics and Society. No.5. pp. 104-107.

Hacharoevsky, A.A. The Modern Doctrine of Jihad [Electronic resource] // Website "Caucasus Emirate» URL: http://hunafa.com/?p=134 54.

History of Assassins. [Electronic resource] // Website "History of Assassins» URL: http://artassassins.narod.ru/lndex.html.

Lewis, B. (2003) The crisis of Islam: Holy War and Unholy Terror. NewYork. pp. 109.

Lawrence of Arabia [Electronic resource] // biographical site URL: http://allpersons.name/index.php?option= com_content\& task=view\& id $=473 \&$ ltemid $=17$.

The Leader of ISIS Called for "Universal Jihad» // http://www.aif.ru/society/safety/1381626.

A new quality of terrorist propaganda: media empire ISIS // http://spkurdyumov.ru/biology/novoe-kachestvo-terroristicheskoj-propagandymediaimperiya-igil/.

The French White Paper on defence and national security http://www.elysee.fr/download/?mode=press\&filename=Dossier_de_presse LLBlanc_DSN_en_anglais.pdf.

http://gordonua.com/news/society/Daydzhest-7-yanvarya-Terakt-v-Parizhe-evro-i-neft-upali-morozy-v-Ukraine-60097.html.

Thor, V.V. (2014) British Muslim Identity in Multicultural Conditions // Philosophy and Culture. No. 1. pp. 104-107.

http://www.nvspb.ru/stories/dobro-pojalovatotsyuda-44722.

Malik, K. (2013) Multiculturalism and Its Discontents: Rethinking Diversity After 9/11. Seagull Books.

http://iph.ras.ru/uplfile/histan/kruglye_stoly_pdf/chto_oznachaet_krah_mulwthkulwturalhzma_.pdf.

Behloul, S.M., Leuenberger, S. \& Tunger-Zanetti, A. (2014) Debating Islam: Negotiating Religion, Europe, and the Self. Transcript Verlag.

http://www.utro.ru/articles/2011/02/11/955701.shtml.

Gorbenko, A.I. (2014) Terrorism as an Antisocial Phenomenon in Russian Society: Sociological Analysis // Actual Problems of Modern Socio-Cultural Space: collection of research papers adapted from All-Russian Scientific and Practical Conferention / Edited by Shalin V. V. Krasnodar: KubGAU. pp. 46.

Herbert, D. (2013) Creating Community Cohesion: Religion, Media and Multiculturalism. Palgrave Macmillan.

Demetradze, M.R. (2014) Problems of Non-Compliance of Social and Cultural Policy of Russia to Processes of Global Modernization /I Law and Politics. No. 1. pp. 23-30.

Abbas, T. (2011) Similar statistics we can find in other countries. Islamic Radicalism and Multicultural Politics: The British Experience. Taylor \& Francis.

The Shanghai Convention on Terrorism, Separatism and Extremism Combating (2001) Shanghai, June 15, 2001) // Collected Legislation of the Russian Federation dated October 13, 2003 No.41. Art. 3947. 